\title{
INTRODUCTION
}

\section{Environments of Italianness: for an environmental history of Italian migrations}

\author{
Roberta Biasillo $^{1 *}$ (D) Claudio de Majo $^{2}$ and Daniele Valisena ${ }^{3 \dagger}$ \\ ${ }^{1}$ Robert Schuman Centre for Advanced Studies, European University Institute, San Domenico di Fiesole, Italy \\ ${ }^{2}$ Rachel Carson Center for Environment and Society, Ludwig-Maximilians University, Munich, Germany \\ ${ }^{3}$ KTH Environmental Humanities Laboratory, Royal Institute of Technology, Stockholm, Sweden
}

(Received 16 February 2021; final version accepted 24 March 2021)

\begin{abstract}
Italian mobility played a fundamental part in the history of the peninsula, since it was a global phenomenon reaching every continent except Antarctica. The Italian diaspora counted over 26 million expatriates who left the country between 1876 and 1976 and, to date, Italy remains one of the states that has contributed the most to the Great European Migration. Although impressive, these figures do not take into account pre-unitary Italian mobilities or Italian settlements in colonial territories. By adopting the perspective of environmental history of migration, this collection of essays allows us to consider various contextually embedded migratory environments, creating a means to find common constitutive features that allow us to explore and identify Italianness. Specifically, in this special issue, we intend to investigate how Italians transformed remote foreign environments in resemblances of their distant faraway homeland, their paesi, as well as used them as a means of materially re-imagining landscapes of Italianness. In return, their collective and individual identities were transformed by the new surroundings.
\end{abstract}

Keywords: environmental history; migration; Italianness; agriculture; colonialism.

Italian mobility is arguably older than Italy itself, a global phenomenon touching every continent except Antarctica. As a long-standing constituent of rural societies inhabiting the Italian peninsula, mobility has generated diverse patterns of movement over time - from transhumance to seasonal and circular migrations, from intra-European and Mediterranean flows to overseas definitive transfers (Audenino and Tirabassi 2008; Sanfilippo 2005). The Italian Diaspora, as framed by eminent scholar Donna Gabaccia $(2000,1)$, counted over 26 million expatriates who left the country between 1876 and 1976 and, to date, Italy remains one of the states that has contributed the most to the Great European Migration (Bade 2003, 110-17). ${ }^{1}$ Although impressive, those figures do not take into account pre-unitary Italian mobilities or Italian settlements in colonial territories, which this special issue aims to include.

We are well aware that the environment is often a hidden guest in influential historiographical works reconstructing Italian migratory flows. Stories of Italians farmers in South America (Zannini and Gazzi 1993; Brunello 1994; Franzina 2000; Canovi 2009; Gallo 1983), the US (Martellini 2001; Gumina 1978), France (Teuillières 2012), North Africa (Cresti 1996; Cresti 2011) and East Africa (Ertola 2017) are well explored, as are stories of Italian labourers in Belgium (Cumoli 2009; Morelli 2004), Switzerland (Barcella 2018), Germany (Petersen 1993), Australia

\footnotetext{
†Emails: roberta.biasillo@eui.eu; claudio.demajo@ rcc.lmu.de; valisena@kth.se
} 
(Baldassar 2001), Canada (Ramirez 1990; Iacovetta 1992) and the UK (Colucci 2009). Despite their successes, none of these historiographical reconstructions framed their accounts with the environment at the centre of their analysis, in terms of content, structure or methodology. In order to reconfigure this framing, this special issue encompasses cases of Italian mobility by adopting the perspective of environmental history. Following Fisher (2020), we intend to analyse how Italians transformed and used distant foreign environments in order to resemble their distant faraway homeland, their paesi, as well as a way to materially re-imagine landscapes of Italianness. In return, their collective and individual identities were transformed by the new surroundings.

As Marco Armiero and Richard Tucker (2017) wrote in their ground-breaking edited volume on the environmental history of migrations (hereafter EHM), 'migrants are nature on the move'. As they travel, work, and dwell in foreign lands they bring along their ecological reasoning, as well as vast and diverse toolkits of practices, seeds, animals, cultures, and perceptions of the environment. Whilst the relationship between settlers and the environment has long been at the centre of analysis in American environmental history (Crosby 1973; Cronon 1983; Richards 2003), much less attention has been paid to the active ecological role of migrants in shaping their immigration land, with some notable exceptions (Rome 2008; Nash 2006, Mitchell 1996; Kraut 1994). Recently, a few authors have investigated the nexus between leisure spaces, urban environmental history, and migration (Fisher 2015; McCammack 2017), while others have focused on state-led internal colonisation projects (Nobbs-Thiessen 2020). North American environmentalists and the early conservation movement have often blamed immigrants for harming the beauty of the American environment (Warren 1999) or as carriers of threatening invasive species (Coates 2007). In urban environments, migrants' ecologies have long been blamed as retrograde and unfit for modern times (Mazzoli and Valisena 2020; McNeur 2014).

By combining both scholarships of Italian mobility history and EHM, this collection of essays allows us to consider various contextually embedded migratory environments, creating a means to find common constitutive features that allow us to explore and identify Italianness.

What emerges in all the essays is an explicit link between migration, agriculture and colonisation, where colonisation refers to the set of strategies that states (such as Italy, the USA, Argentina, Brazil and Russia) adopted to expand the agricultural frontier within their national and colonial borders. Indeed, Mark Choate (2008) in his essay Emigrant Nation: The Making of Italy Abroad argues that this nexus seems to be a common aspect of Italian migration and underlines the unique entanglement between the history of Italian 'free emigrants' colonies' (the so-called 'colonie libere') and imperial 'demographic colonies' in North and East Africa. There is a continuous aspect of expanding European agriculture at the expense of local and native systems, coupled with the impact of Italian communities settled abroad in different ways but always within a particular political framework. The expansion of agricultural frontiers at the expense of allegedly unproductive forests, wastelands and desert, with the rhetoric of civilisation and the transfiguration of foreign spaces as legible and familiar environments, were political instruments of control for either Italy, or for ruling governments in the countries of arrival. In certain cases, those two aspects coincided, as Gilberto Mazzoli (2021, this issue) synthesises as the expression of 'agricultural diplomacy'. This was especially the case during the Fascist era, when all those elements intertwined to the point that Italian migration and colonisation were no longer considered two independent processes (Labanca 2007; Choate 2008, 2, 14; Pergher 2019). The awareness of this colonial implication of Italian migration draws us to pay attention to pre-colonial landscapes and to forms of injustice and violence embedded in socio-environmental transformations. This conundrum deeply influenced the formation of the very idea of Italian mobilities outside the madrepatria, as well as 
informing Italian state policies on emigration, colonisation and even continuing to present-day immigration (Ben Ghiat and Hom 2016; Hom 2019).

The analysed schemes channelling Italian rural workers abroad generated and relied on an idealised image of the Italian migrant, alongside a romanticised picture of the Italian landscape. Who was the ideal Italian migrant then? Mostly a loyal farmer who was attached to his own plot of land, morally and with his particular skills crafted to be a perfect owner, able to cooperate and create an exclusive white settler society in a new environment, the famous 'Little Italies' (Gabaccia 2006). Those narratives collide with the fact that Italians never came first, anywhere. They were not earlycomers in the scramble for Africa; neither were they the first choice for Latin American and North American governments. Other nations took over the 'best' overseas territories and other European nationalities would have been preferred over Italians to improve vast expanses on the other side of the Atlantic. Due to these forced combinations, the forge of environmental imaginaries, long-term Italian migratory culture and its interrelationship with natural factors played a major role compared to other national communities migratory flows. The role of memories and biomes, the connection between place-based stories and transnational narratives, oral history and discourse analysis methodologies appears key to unveiling this tension.

Another common element is that in several migratory instances, original rural and regional lifestyles and practices not only persisted but actually flourished in their new contexts. As anthropologist Ernesto De Martino (1977) described, senses of belonging for mobile subjects are played around practices of appaesamento. The expression hardly translates into English, but can be understood as recognising oneself as of, from and part of the paese (the village but also the country). This very issue of Italian paese/Paese and the rematerialisation of individual and collective spaces of belonging cut across all the cases, blurring the dichotomies of rural space versus urban space and colonised versus colonisers (Italian coloni). The environments of Italianness were, as a matter of fact, spaces of resistance to top-down schemes and ways of adjustment to conditions on the ground.

The five essays featured in this special issue aim to offer a broad - although still partial overview on the socio-ecologies of Italian mobility. Spanning from the 1820s to the 1940s, these essays analyse well-known migration routes, such as those connecting Italy with Argentina, Brazil, and the United States, together with less-famous settler colonies such as that of Kerch in Tzarist Russia's Crimea, and the colonial territory of Libya. We focus on Italian mobilities as we believe that the global extent of Italian wayfaring across the world offers a unique vantage point for studying the agency of migrants in transforming foreign environments. On the other hand, the grand environmental transformation plans developed by Fascism (Armiero 2014) and the Italian liberal state might encourage post-colonial scholars to further explore Italian colonialism and its legacy within racialised present-time narratives of Italianness.

We know that this special issue is just the beginning of our engagement with the EHM and we recognise that each paper deals with an extremely partial definition of the environment. De Majo and Peruchi Moretto pay a lot of attention to ecological aspects - the forest biome, environmental hazards, plant varieties; Valisena and Canovi rather look at the cultural dimension of the environment and use the very Italian category of landscape; Rojas Gomez considers the economic use of natural resources between solo and collective practices; in Mazzoli's paper the environment mainly consists of the space for diplomatic and political cooperation; finally, in Biasillo's article the environment becomes a tool for an authoritarian government to rule and create consensus. Besides these aspects, environmental history can potentially embrace many other elements that do not appear in this special issue. As an example, scientific and technological dimensions are not explored and the same goes for encounters between different systems of knowledge and farming practices. 


\section{Acknowledgements}

This special issue is the outcome of a panel organised at the Third World Congress of Environmental History that took place in Florianopolis (Brazil) in July 2019, followed by a roundtable hosted in August 2020 by the online event Streaming STREAMS at the KTH Environmental Humanities Laboratory in Stockholm. We wish to thank the organising and scientific committees of both meetings for providing us with an initial space for interaction and exchange. On both occasions we received constructive and insightful feedback from Eunice Sueli Nodari and Ilaria Vanni Accarigi.

A special mention goes to Marco Armiero, to whom several of the contributors of this issue owe a debt of gratitude for his personal and intellectual generosity. He agreed to discuss key methodological knots and aspects of EHM with us in the interview that follows our essays. A second special mention goes to Stephanie Malia Hom, who promptly accepted our invitation to join our proposal and to anchor this special issue with a beautifully written final commentary.

Thanks to our anonymous reviewers for their to-the-point suggestions, and to the copy-editors for kindly assisting us in the production phase of our essays.

Needless to say, this issue would have not been possible without the support of the journal Modern Italy and we are sincerely grateful to former editors, Penelope Morris and Mark Seymour, for their encouragement and support, and to the current ones, Francesca Billiani and Andrea Mammone, for their finalising efforts.

We hope that this special issue will continue its life as it started, as a forum for discussion between different generations of scholars.

\section{Notes on contributors}

Roberta Biasillo is a Max Weber Fellow at the European University Institute in Florence. She holds a PhD in Early Modern and Modern European History from the University of Bari (Italy) and her thesis focused on the role of forests in the state- and nation-building processes in Italy. She has worked at the KTH Environmental Humanities Laboratory in Stockholm and at the Rachel Carson Center in Munich. She is currently researching on the environmental history of Italian colonialism in Africa.

Claudio de Majo is a PhD candidate in Environmental Humanities at the Rachel Carson Center for Environment and Society (Ludwig-Maximilians University, Munich). He has carried out research with the University of Naples L'Orientale, the Institute for Housing and Urban Development Studies at Erasmus University of Rotterdam, the University of Utrecht and the Federal University of Minas Gerais, Belo Horizonte (Brazil). His main research interests include the relation between the commons and ecology, evolutionary history and the environmental history of Italy and Brazil. He is a founding member of the American Studies academic journal JAm It! and associate editor of Global Environment.

Daniele Valisena is a $\mathrm{PhD}$ in History of Science, Technology and Environment. His doctoral fellowship was part of the EU funded Marie Sklodowska-Curie ITN ENHANCE (grant agreement 642935) in environmental humanities. His research deals with the interplay between environmental history and migration, touching upon heritage and memory studies, oral history and environmental humanities. He is one of the co-editors of the present special issue.

\section{Notes}

* The names of the authors are listed here in alphabetic order. They have contributed equally to this introduction.

1. According to Klaus Bade (2003, 110-17), 18 million people left Italy between 1871 and 1924, 7.3 million of which migrated to the Americas. Italy was the second most important contributor to the Great European Migration as a region after the British Isles (Ireland was still part of the UK until 1921). 


\section{References}

Armiero, M. 2014. 'Special Issue on Fascism and Nature'. Modern Italy 19 (3).

Armiero, M. and R. Tucker. 2017. Environmental History of Modern Migration. London-New York: Routledge.

Audenino, P. and M. Tirabassi. 2008. Migrazioni italiane. Storia e storie dall'Ancien régime ad oggi. Milan: Mondadori.

Bade, K. 2003. Migration in European History. Oxford: Blackwell.

Baldassar, L. 2001. Visits Home: Migration Experiences between Italy and Australia. Melbourne, Australia: Melbourne University Press.

Barcella, P. 2018. Per cercare lavoro. Donne e uomini nell'emigrazione italiana in Svizzera. Rome: Donzelli. Brunello, P. 1994. Pionieri. Gli italiani in Brasile e il mito della frontiera. Venice: Marsilio.

Canovi, A. 2009. Pianure migranti. Un'inchiesta geostorica tra Emilia e Argentina. Reggio Emilia: Diabasis. Choate, M. 2008. Emigrant Nation. The Making of Italy Abroad. Cambridge MA: Harvard University Press. Coates, P. 2007. American Perceptions of Immigrant and Invasive Species: Strangers on the Land. Berkeley: University of California Press.

Colucci, M. 2009. Italiani in Gran Bretagna dopo la seconda guerra mondiale. Foligno: Editoriale Umbra.

Cresti, F. 1996. Oasi d'italianità. La Libia della colonizzazione agraria tra fascismo, guerra e indipendenza (1935-1956). Turin: SEI.

Cresti, F. 2011. Non desiderare la terra d'altri. La colonizzazione italiana in Libia. Vol. 1. Rome: Carocci.

Cronon. W. 1983. Changes in the Land: Indians, Colonists, and the Ecology of New England. New York: Hill \& Wang.

Crosby, A. 1973. The Columbian Exchange: Biological and Cultural Consequences of 1492. Santa Barbara, CA: Greenwood.

Cumoli, F. 2009. 'Perdus dans le paysage: la prolongation de la culture rurale italienne dans les bassins miniers de Wallonie'. Journal of Belgian History 37 (3-4): 419-33.

De Martino, E. 1977. La fine del mondo. Turin: Einaudi.

Ertola, E. 2017. In terra d'Africa. Gli italiani che colonizzarono l'impero. Rome-Bari: Laterza.

Fisher, C. 2015. Urban Green: Nature, Recreation, and the Working Class in Industrial Chicago. Chapel Hill: University of North Carolina Press.

Fisher, C. 2020. 'The Crossroads of U.S. Environmental History and Migration History', JAm It! 3: 12-26.

Franzina, E. 2000. Merica! Merica! Emigrazione e colonizzazione nelle lettere dei contadini veneti in America Latina, 1876-1902. Verona: Cierre.

Gabaccia, D. 2000. Italy's Many Diasporas. London-New York: Routledge.

Gabaccia, D. 2006. 'Global Geography of "Little Italy": Italian Neighbourhoods in Comparative Perspective'. Modern Italy 11 (1): 9-24.

Gallo, E. 1983. La pampa gringa. La colonización agrícola en Santa Fe (1870-1895). Buenos Aires: Sudamericana.

Ben Ghiat, R. and S. Hom. 2016. Italian Mobilities. London-New York: Routledge.

Gumina, D. P. 1978. The Italians of San Francisco. New York: Center for Migration Studies.

Hom, S. 2019. Empire's Mobius Strip. Historical Echoes in Italy's Crisis of Migration and Detention. Ithaca, NY: Cornel University Press.

Iacovetta, F. 1992. Such Hardworking People: Italian Immigrants in Postwar Toronto. Montreal: McGill-Queen's Press.

Kraut, A. 1994. Family and Community: Italian Immigrants in Buffalo, 1880-1930. Ithaca, NY: Cornell University Press.

Labanca, N. 2007. Oltremare. Storia dell'espansione coloniale italiana. Bologna: Il Mulino.

Martellini, A. 2001. 'Il commercio dell'emigrazione: intermediari e agenti'. In Storia dell'emigrazione italiana Vol 1: Partenze, edited by A. Bevilacqua, A. De Clementi and E. Franzina, 293-308. Rome: Donzelli.

Mazzoli, G. 2021. 'Italianness in the United States between Migrants' Informal Gardening Practices and Agricultural Diplomacy 1880-1912'. Modern Italy 26 (2). 
Mazzoli, G. and D. Valisena. 2020. 'Migrant Ecologies in the Press: Chicago Italians and the Tribune'. JAm It! 3: 29-39.

McCammack, B. 2017. Landscapes of Hope: Nature and the Great Migration in Chicago. Cambridge, MA: Harvard University Press.

McNeur, C. 2014. Taming Manhattan. Cambridge, MA: Harvard University Press.

Mitchell, Don. 1996. The Lie of the Land. Migrant Workers and the California Landscape. Minneapolis: University of Minnesota Press.

Morelli, Anne. 2004. Gli italiani in Belgio. Storia e storie di due secoli di migrazioni. Foligno: Editoriale Umbra.

Nash, L. 2006. Inescapable Ecologies: A History of Environment, Disease, and Knowledge. Berkeley: University of California Press.

Nobbs-Thiessen, B. 2020. Landscape of Migration: Mobility and Environmental Change on Bolivia's Tropical Frontier, 1952 to the Present. Chapel Hill: University of North Carolina Press.

Pergher, R. 2019. Mussolini's Nation-Empire. Cambridge: Cambridge University Press.

Petersen, J., ed. 1993. L'emigrazione tra Italia e Germania. Manduria-Bari-Roma: Lacaita Editore.

Ramirez, B. 1990. On the Move: French-Canadian and Italian Migrants in the North Atlantic Economy 1860-1914. Toronto: McClelland \& Stewart.

Richards, J. F. 2003. The Unending Frontier. An Environmental History of the Early Modern World. Berkeley: University of California Press.

Rome. A. 2008. 'Nature Wars, Culture Wars: Immigration and Environmental Reform in the Progressive Era'. Environmental History 13: 432-53.

Sanfilippo, M. 2005. Problemi di storiografia dell'emigrazione italiana. Viterbo: Sette Città.

Teuillières, L. 2012. Immigrés d'Italie, paysans de France 1920-1944. Toulouse: Mirail.

Warren, L. 1999. The Hunter's Game: Poachers and Conservationists in Twentieth-Century America. New Haven: Yale University Press.

Zannini, A. and D. Gazzi. 1993. Contadini, emigranti, 'colonos'. Tra le Prealpi venete e il Brasile meridionale: storia e demografia, 1780-1910. Treviso: Edizioni Canova.

\section{Italian summary}

Le forme di mobilità degli italiani rappresentano un aspetto fondamentale della storia della penisola, ma non solo, poiché le comunità italiane hanno raggiunto tutti i continenti, fatta eccezione per l'Antartico. Nel periodo tra il 1876 e il 1976, la 'diaspora italiana' ha coinvolto più di 26 milioni di persone, facendo dell'Italia uno degli stati che più ha contribuito al fenomeno della Grande Emigrazione europea. A questi dati bisogna altresì aggiungere quelli relativi alle mobilità preunitarie e a quelle verso le colonie, argomenti inclusi tra $\mathrm{i}$ saggi qui raccolti. Adottando pertanto la prospettiva della storia ambientale delle migrazioni e muovendo dalle ricerche presentate nei singoli saggi, i curatori propongono una sintesi delle caratteristiche socio-ambientali che hanno influenzato e caratterizzato l'emergere di identità italiane all'estero, ovvero forme di italianità. Gli articoli contenuti in questo numero monografico illustrano come italiani e italiane abbiano trasformato e utilizzato gli ambienti naturali stranieri per ricostruire le proprie piccole patrie, i loro paesi. Allo stesso tempo, questi nuovi paesaggi dell'italianità hanno contribuito a formare identità ibride, collettive e individuali. 